\title{
The concept of professional identity: Kindergarten teachers' professionalism requirement in Malaysian preschool curriculum
}

\author{
Abdul Halim Masnan', Muhammad Haziq Mohd Sharif ${ }^{2}$, Masayu Dzainuddin ${ }^{3}$, Mohd Mokhzani \\ Ibrahim $^{4}$, Asmayati Yahaya ${ }^{5}$, Che Nidzam Che Ahmad ${ }^{6}$, Hafsah Taha ${ }^{7}$, Saipolbarin Ramli ${ }^{8}$, \\ Rosfizah Md Taib ${ }^{9}$, Saedah Siraj ${ }^{10}$, Mazlina Che Mustafa ${ }^{11}$ \\ $1,2,3,4,5,6,7,8,9,10$ Sultan Idris Education University, Malaysia \\ ${ }^{11}$ National Child Development Research Centre, Sultan Idris Education University, Malaysia
}

\begin{tabular}{|c|c|}
\hline Article Info & ABSTRACT \\
\hline Article history: & \multirow{10}{*}{$\begin{array}{l}\text { This study aimed to determine the professional identity concept based on } \\
\text { professionalism requirement in Malaysia's new preschool curriculum. Three } \\
\text { professional identities identified through works of literature such as } \\
\text { professional qualifications, experience and professional development were } \\
\text { verified based on the constructed hypothesis to validate the concept of } \\
\text { professional identity. The analysis findings showed a significant difference } \\
\text { between professional qualifications. The same analysis, however, } \\
\text { demonstrated that there was no significant difference on the preschool } \\
\text { curriculum knowledge with regards to experience, but there was a significant } \\
\text { indication of interaction between professional qualifications and experience } \\
\text { on preschool curriculum knowledge. Meanwhile, for the one-way ANOVA } \\
\text { test, there was a significant difference in the preschool curriculum knowledge } \\
\text { based on professional development. The findings of this study confirmed that } \\
\text { professional knowledge and professional development respectively hold a } \\
\text { direct impact on the preschool curriculum, while experience acts as a support } \\
\text { for professional qualifications. }\end{array}$} \\
\hline Received Jun 9, 2020 & \\
\hline Revised Dec 20, 2020 & \\
\hline Accepted Jan 28, 2021 & \\
\hline Keywords: & \\
\hline Experience & \\
\hline New preschool curriculum & \\
\hline Professional development & \\
\hline Professional qualifications & \\
\hline Professionalism & \\
\hline
\end{tabular}

This is an open access article under the CC BY-SA license.

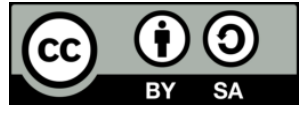

\section{Corresponding Author:}

\author{
Abdul Halim Masnan \\ Department of Early Childhood Education \\ Sultan Idris Education University \\ Tanjong Malim, Perak Darul Ridzuan 35900, Malaysia \\ Email: abdul.halim@fpm.upsi.edu.my
}

\section{INTRODUCTION}

The concept of professional identity is not straightforward. It can be summed up by stating that it is inextricably linked to personal identity; it is not fixed but dynamic; it is multi-faceted; and the definition of human agency is linked to changes in professional identity. Malaysia's ministry of education (MOE) has coordinated the national preschool curriculum (NPC) as the nation's first preschool curriculum to all kindergarten and preschools in the National Education System prescribed under the subsection 22(1) Education Act 1996 (Act 550). Through Professional Circular Letter No. 15/2002, MOE had prescribed the use of NPC to all levels of government and private preschools [1]. In brief, after five years of implementation of NPC since 2003, MOE had conceptualized this preschool curriculum to the national standard preschool curriculum (NSPC), and subsequently, the implemented NSPC in 2010 underwent a review resulting NSPC (Revised 2017) to comply with the new policy of Malaysia education blueprint (MEB) 2013-2025, the current requirement, and to ensure that the quality of the curriculum is aligned with the international standard [2-4]. 
The transformation of the preschool curriculum had unequivocally demonstrated the Malaysian government's commitment to developing the quality of preschool education. However, the curriculum development alone without proper execution would not ensure the quality in education [5]. The transformation of the standard-based curriculum in NSPC demands highly professional teachers as they would be required to implement the teaching, which is up to the standard and needs of the students. Similarly, a continuous assessment of the children should be applied to align with the National Education Philosophy and NSPC during teaching and learning (T\&L) [6]. Therefore, comprehensibly, the effectiveness of a preschool curriculum does not only rely on the planning and developing but its professional implementers.

Beaver, et al. [7] stated, curriculum outlined the expectations on skills, performance, attitude and values for the children's learning. For professional teachers, they would always be applying their knowledge and considering the most efficient learning materials, interactions and experience for the children. Thus, the effectiveness of a preschool curriculum is undeniably dependent on professional preschool or kindergarten teachers. Local researches had evidently shown that teachers with professional identity such as professional qualifications [8], experience [9, 10] and professional development [10] held more understanding and implemented T\&L which was aligned with the principles and objectives in NSPC. Accordingly, professional identity is not only a requirement to develop professionalism in preschool education but an advancement of knowledge and practices for kindergarten teachers on preschool curriculum [11].

Although professional identity is vital for the effectiveness of preschool education, most of the teachers in preschools and kindergartens across the country were recorded as non-professional teachers. In reference to the MEB 2013-2025 Annual Report, in 2017, only 22,971 (44.4\%) of the total of 51,725 preschool or kindergarten teachers owned professional qualifications at least in Diploma in early childhood care and education (ECCE) while the other 28,754 teachers (55.6\%) had lower professional qualifications [12-14]. In the same report, there was a huge gap of preschool or kindergarten teachers with no minimum qualification of Diploma between the government $(5,527$ teachers) and private $(23,327$ teachers) which amounted to a significant difference of 17,800 teachers $[15,16]$. A survey conducted by Foong, et al. [17] found that a massive number of 3,087 preschool teachers from the private sector across the country were very young, lack in experience had low income and did not hold professional qualifications. They had acknowledged that the private preschool teachers did not meet the minimum qualification of Diploma in ECCE, unlike the government sector. Hence, this situation had urged a study on the professional identity among private kindergartens based on the fact that their teachers held diverse education background ranging from secondary school to degree level.

According to Khalil [18], the development of teacher's professionalism helped the existing and future T\&L process. It stemmed from the fact that the professionalism shown by the teachers was their quality in maintaining professional ethics on the highest standard, standard compliance in the profession, display of lifetime learning on professional development and individual training of professional practices [19]. Professionalism is the ability, skills and execution of a professional individual [18], while professional is the implementation of excellent work, competent worker, display of trust and efficient service. Based on these definitions, professionalism could be simplified as a competency within a teacher, while the professional is a competency required by a teacher to implement work that is in accordance with the teaching profession.

The study of Löfgren [20] stated that professionalism was seen dominant when a professional identity was developed. In early education, the organization for economic cooperation and development (OECD) described that highly educated and professionally-trained personnel were the key to a quality ECCE service. This had also been stated on a local level by Malaysian qualifications agency (MQA) that a quality ECCE service relied on knowledgeable, competent and trained teachers through quality ECCE programs. Nonetheless, the assumption of professional identity was dynamic and referred to diverse aspects [21]. Teacher's professional identity, in fact, were understood differently by foreign researchers through their studies in early education [22] and preschool education [20,21]. This had indicated that unanimity had not been achieved for proper professional identity required by the teachers in the early education field or preschool education. Therefore, the professional identity concept could not be precisely specified. Consequently, the types of professional identities need to be identified based on the local context so that the professional identity concept could be determined by the current preschool requirement in Malaysia.

As stated by Androusou and Tsafos [21], the professional identity for teachers differed according to the theoretical framework, the researcher's view and focus of a study. Based on this statement, the current studies have regarded that professional qualifications, experience and professional development are able to explain the professional identity concept for kindergarten teachers in Malaysia. These indications were identified through national researches by [8], which discovered that the novice preschool teachers with professional qualifications showed effective teaching skills, aligned with the standard NSPC. The study by Amirafiza, et al. [9]; Sofiah and Kamarul [10], on the other hand, had indicated that kindergarten teachers 
with professional qualifications and more than five years of experience had an excellent grasp of NSPC and conducted the T\&L efficiently, reflecting their knowledge. However, a study by Nazri and Nurul [1]; Mardziah, et al. [6] found that preschool teachers with professional qualifications encountered challenges in fulfilling the standard in NSPC. This obviously hinted for professional development since the study by Sofiah and Kamarul [10] had also demonstrated how the courses and pieces of training helped preschool teachers to understand children's development and suitable T\&L techniques in the classrooms. As subject to this feature, the three professional identities are deliberated as professionalism requirement in the new preschool curriculum in Malaysia.

This study is outlined to determine the concept of professional identity for local kindergarten teachers based on the professional requirement in Malaysia's new preschool curriculum. Based on the previous discussion, professional qualifications and professional development were respectively seen to have an impact on the implementation of NSPC, while experience acted as a support to professional qualifications [21-25]. Hence, professional qualifications and professional development are deemed as the direct effects while the experience is the mediator. This study, however, is a preliminary study since the national researches regarding professional identities in early education, either ECCE or preschool education is very limited. Subsequently, this study regards the preschool curriculum knowledge as the foundation before determining the teacher's practices or skills in implementing the curriculum. This is because a study by Ntumi [25] found that preschool teachers' insubstantial knowledge on early childhood curriculum in Cape Coast Metropolis, Ghana was the cause of failure in implementing the curriculum. The effectiveness of students' learning also depended on the teacher's knowledge of the curriculum. It is, therefore, undoubted when the curriculum knowledge had been categorized by Shulman [26] as one of the seven basic knowledge required from the teachers to strengthen students' understanding.

Hence, the current study has suggested two particular objectives to meet the purpose of this study which are: 1) Determining the difference of preschool curriculum knowledge based on professional identities (professional qualifications and experience); and 2) Determining the difference of preschool curriculum knowledge based on professional identities (professional development). Four alternative hypotheses were constructed as Figure 1.

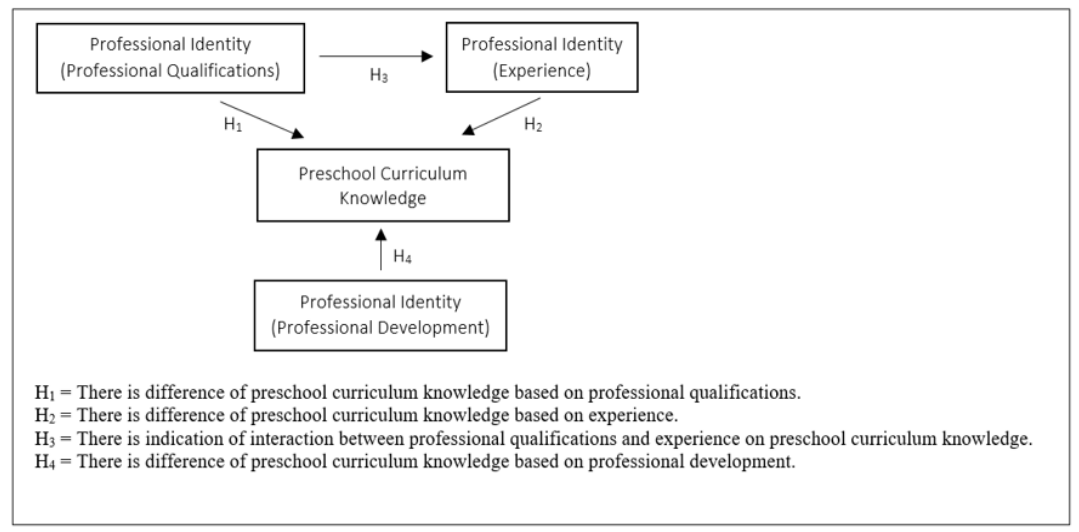

Figure 1. Research framework plan

\section{RESEARCH METHOD}

\subsection{Population and sample}

The population of this study is a total of 929 teachers from private kindergarten institutions which were registered under Private Education Division, MOE in a district in Selangor. To determine a sample size based on a significance level p<0.05, the Table of Determining Sample Size was referred [27]. Consequently, this study involved 269 teachers from private kindergartens a district in Selangor who were appointed to conduct early or preschool education programs and the appointment process as well as an allowance or salary payment was administered by the institution itself. The selection of the sample was made via stratified random sampling.

\subsection{Instrument}

This study used a questionnaire instrument on Preschool Curriculum Knowledge among Private Kindergarten Teachers which was modified from the questionnaire of The Quality of Early Childhood Care 
and Education in Malaysia developed by Ahmad, et al. [28] for the use of the National Child Development Research Centre in Sultan Idris Education University for the Research Project of Evaluation of Existing ECCE Program to Improve Quality that Inform Policy (P1/CUR). The questionnaire was modified to have the validity (Scale Content Validity Index $[\mathrm{S}-\mathrm{CVI} / \mathrm{Ave}]=0.907$, average Kappa coefficient value $\left[\mathrm{k}^{*}\right]=0.757$ ) and excellent reliability (Cronbach Alpha $[\alpha]=0.961$ ).

\subsection{Procedures and measurement}

The data of this study was obtained through a survey questionnaire that was self-administered as well as administered with a number of P1/CUR researchers. The distribution of the questionnaire was directly made to the samples through kindergarten operators and supervisors and during the organization of the seminar program with the private kindergartens. It was also done through mailing. 302 questionnaires were successfully collected from the samples. However, only 269 of them were successfully sorted by stratification to meet the conditions for the ANOVA test. The score was analyzed using the service package for the social sciences (SPSS) software version 23 involving inferential statistics using two-way and one-way ANOVA to determine the discrepancies.

\section{RESULTS}

\subsection{The difference between preschool curriculum knowledge based on professional qualifications and} experience

Analysis from the two-way ANOVA test had found that there was a significant difference in preschool curriculum knowledge depending on the professional qualifications groups $(\mathrm{F}[2,260]=3.499$, $\mathrm{p}=0.032$ ). With results as displayed in Table 1, H1 was accepted, and the Post Hoc Test was referred.

Table 1. The results of the two-way ANOVA test for professional qualifications and experience

\begin{tabular}{cccccc}
\hline Main indication & Total square & Degrees of freedom $(\mathrm{df})$ & Mean square & F value & Significance \\
\hline Professional qualifications & 0.964 & 2 & 0.482 & 3.499 & 0.032 \\
Experience & 0.075 & 2 & 0.038 & 0.273 & 0.761 \\
Professional qualifications*Experience & 1.655 & 4 & 0.414 & 3.005 & 0.019 \\
Error & 35.813 & 260 & 0.138 & & \\
Total & 3225.433 & 269 & & & \\
\hline
\end{tabular}

Note: *significance at level $\mathrm{p}<0.05$

Referring to Table 2, private kindergarten teachers with professional qualifications in Diploma in ECCE/Preschool Education and above $(\mathrm{M}=3.520, \mathrm{SD}=0.389)$ showed higher preschool curriculum knowledge than ECCE/Preschool Teaching Certificates $(\mathrm{M}=3.379, \mathrm{SD}=0.366)$ and None $(\mathrm{M}=3.422, \mathrm{SD}=0.372)$. However, by employing Post Hoc Test using Tukey's HSD as shown in Table 3, there was obviously the significant difference between the groups of Diploma in ECCE/Preschool Education and above and ECCE/Preschool Teaching Certificates ( $\mathrm{M}$ difference=0.141, $\mathrm{p}=0.046$ ). For the Diploma in ECCE/Preschool Education with None, there was no significant mean value discrepancy $(\mathrm{M}$ difference $=0.098, \mathrm{p}=0.160$ ).

Table 2. Distribution of preschool curriculum knowledge based on professional qualifications

\begin{tabular}{cccc}
\hline Professional qualifications & Frequency (f) & Mean $(\mathrm{M})$ & Standard deviation (SD) \\
\hline None & 109 & 3.422 & 0.372 \\
ECCE/Preschool teaching certificates & 73 & 3.379 & 0.366 \\
Diploma in ECCE/Preschool education and above & 87 & 3.520 & 0.389 \\
Total & 269 & 3.442 & 0.379 \\
\hline
\end{tabular}

Table 3. Results of post hoc test for professional qualifications

\begin{tabular}{|c|c|c|c|c|}
\hline \multirow{2}{*}{\multicolumn{2}{|c|}{ Professional qualifications }} & \multicolumn{3}{|c|}{ Tukey's HSD comparison } \\
\hline & & \multirow{2}{*}{$\begin{array}{c}\begin{array}{c}\text { Mean } \\
\text { difference }\end{array} \\
0.043\end{array}$} & \multirow{2}{*}{$\begin{array}{l}\text { Error } \\
0.057\end{array}$} & \multirow{2}{*}{$\frac{\text { Significance }}{0.724}$} \\
\hline None & ECCE/Preschool teaching certificates & & & \\
\hline $\begin{array}{l}\text { ECCE/Preschool teaching } \\
\text { certificates }\end{array}$ & $\begin{array}{c}\text { Diploma in ECCE/Preschool education } \\
\text { and above }\end{array}$ & $0.141^{*}$ & 0.060 & 0.046 \\
\hline $\begin{array}{c}\text { Diploma in ECCE/Preschool } \\
\text { education and above }\end{array}$ & None & 0.098 & 0.054 & 0.160 \\
\hline
\end{tabular}


The analysis results of the similar two-way ANOVA test on the abovementioned Table 1 also discovered no significant difference in preschool curriculum knowledge based on experience $(\mathrm{F}[2,260]=0.273, \mathrm{p}=0.761)$. This indicated that private kindergarten teachers with experience of fewer than three years, 3-6 years and more than six years had similar preschool curriculum knowledge. Hence, $\mathrm{H} 2$ was rejected. Nonetheless, there was still a significant indication of interactions between professional qualifications with experience towards preschool curriculum knowledge which was value $F(4,260)=3.005, p=0.019$. Hence, H3 was accepted.

Specifically, the interactions between professional qualifications and experience were inverse. Referring to Table 4, private kindergarten teachers in the group Diploma in ECCE/Preschool Education and above with experience of fewer than three years showed the highest preschool curriculum knowledge $(\mathrm{M}=3.611, \mathrm{SD}=0.395)$. The second highest was from the group non-professionally qualified with experience of more than six years $(\mathrm{M}=3.550, \mathrm{SD}=0.347)$ and the third-highest was from the group Diploma in ECCE/Preschool Education and above with experience of 3-6 years $(\mathrm{M}=3.514, \mathrm{SD}=0.385)$. For the group Diploma in ECCE/Preschool Education and above with experience of more than six years displayed the fourth and least preschool curriculum knowledge $(\mathrm{M}=3.473, \mathrm{SD}=0.387)$. This inverse interaction was more apparent on the graph line in Figure 2.

Table 4. Distribution of preschool curriculum knowledge based on interactions of professional qualifications and experience

\begin{tabular}{cccc}
\hline Professional qualifications + Experience & Frequency (f) & Mean (M) & Standard deviation (SD) \\
\hline None, Less than three years & 41 & 3.339 & 0.374 \\
None, 3-6 years & 26 & 3.346 & 0.363 \\
None, More than six years & 42 & 3.550 & 0.347 \\
ECCE/Preschool teaching certificates, Less than 3 years & 15 & 3.302 & 0.402 \\
ECCE/Preschool teaching certificates, 3-6 years & 20 & 3.488 & 0.363 \\
ECCE/Preschool teaching certificates, More than 6 years & 38 & 3.352 & 0.350 \\
Diploma in ECCE/Preschool education and above, Less than three years & 24 & 3.611 & 0.395 \\
Diploma in ECCE/Preschool education and above, 3-6 years & 19 & 3.514 & 0.385 \\
Diploma in ECCE/Preschool education and above, More than six years & 44 & 3.473 & 0.387 \\
Total & 269 & 3.442 & 0.379 \\
\hline
\end{tabular}

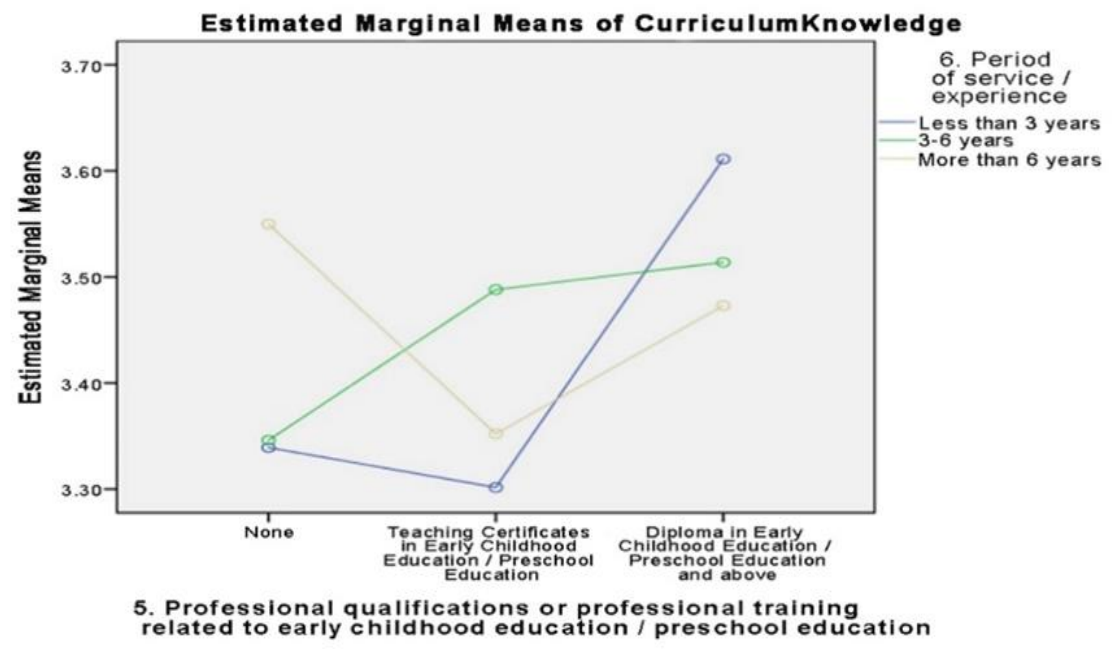

Figure 2. Line graph of interaction between professional qualifications and experience on preschool curriculum knowledge

\subsection{The difference between preschool curriculum knowledge based on professional development}

Inferential analysis using one-way ANOVA test as Table 5 found that there was a significant difference in preschool curriculum knowledge based on professional development ( $\mathrm{F}[5,263]=2.879$, $\mathrm{p}=0.015)$. Hence, H4 was accepted, and Post Hoc Test was further referred. 
Table 5. Result of one-way ANOVA test for professional development

\begin{tabular}{cccccc}
\hline $\begin{array}{c}\text { Preschool curriculum knowledge } \\
\text { based on professional development }\end{array}$ & $\begin{array}{c}\text { Total } \\
\text { square }\end{array}$ & $\begin{array}{c}\text { Degrees of } \\
\text { freedom }(\mathrm{df})\end{array}$ & $\begin{array}{c}\text { Mean } \\
\text { square }\end{array}$ & F value & Significance \\
\hline Intergroup & 1.995 & 5 & 0.399 & 2.879 & 0.015 \\
Intragroup & 36.451 & 263 & 0.139 & & \\
Total & 38.446 & 268 & & & \\
\hline Note: $*$ significancen & & &
\end{tabular}

Note: *significance at level $\mathrm{p}<0.05$

Referring to Table 6, teachers from Others group $(\mathrm{M}=3.655, \mathrm{SD}=0.340)$ displayed the highest preschool curriculum knowledge. The second highest was from the group KAP $(\mathrm{M}=3.568, \mathrm{SD}=0.316)$, followed by NSPC Courses ( $\mathrm{M}=3.458, \mathrm{SD}=0.358)$, SKM Courses $(\mathrm{M}=3.410, \mathrm{SD}=0.355)$, None $(\mathrm{M}=3.393$, $\mathrm{SD}=0.380)$ and finally KAAK $(\mathrm{M}=3.385, \mathrm{SD}=0.410)$. Precisely, the results of Tukey's HSD Post Hoc Test as indicated in Table 7 showed significant mean values discrepancy between professional development groups of Others and None ( $\mathrm{M}$ difference $=0.261, \mathrm{p}=0.024)$. There was also significant mean values discrepancy between professional development groups of Others and KAAK (M difference=0.270, p=0.042). The remaining professional development groups did not show significant difference in mean values.

Table 6. Distribution of preschool curriculum knowledge based on professional development

\begin{tabular}{cccc}
\hline Professional development & Frequency (f) & Mean $(\mathrm{M})$ & Standard deviation $(\mathrm{SD})$ \\
\hline None & 115 & 3.393 & 0.380 \\
NSPC courses & 31 & 3.458 & 0.358 \\
SKM courses & 20 & 3.410 & 0.355 \\
KAAK & 51 & 3.385 & 0.410 \\
KAP & 28 & 3.568 & 0.316 \\
Others & 24 & 3.655 & 0.340 \\
Total & 269 & 3.442 & 0.379 \\
\hline
\end{tabular}

Table 7. Results of post hoc test for professional development

\begin{tabular}{ccccc}
\hline \multirow{2}{*}{ Professional development } & \multicolumn{3}{c}{ Tukey's HSD comparison } \\
& & Mean difference & Error & Significance \\
\hline None & KAAK & 0.009 & 0.062 & 1.000 \\
NSPC courses & None & 0.064 & 0.075 & 0.958 \\
NSPC courses & SKM courses & 0.048 & 0.107 & 0.998 \\
NSPC courses & KAAK & 0.073 & 0.085 & 0.955 \\
SKM courses & None & 0.016 & 0.090 & 1.000 \\
SKM courses & KAAK & 0.025 & 0.098 & 1.000 \\
KAP & None & 0.174 & 0.078 & 0.232 \\
KAP & NSPC courses & 0.110 & 0.097 & 0.866 \\
KAP & SKM courses & 0.159 & 0.109 & 0.694 \\
KAP & KAAK & 0.183 & 0.088 & 0.294 \\
Others & None & $0.261 *$ & 0.084 & 0.024 \\
Others & NSPC courses & 0.197 & 0.101 & 0.376 \\
Others & SKM courses & 0.245 & 0.112 & 0.253 \\
Others & KAAK & $0.270 *$ & 0.092 & 0.042 \\
Others & KAP & 0.087 & 0.104 & 0.960 \\
\hline Note: $*$ means difference at significance level 0.05 & &
\end{tabular}

Note: *means difference at significance level 0.05

\subsection{Discussion}

By using comparative analysis and hypothesis testing, the findings of this study had assisted the validation of the concept of professional identity. In reference to the two-way ANOVA analysis, there was a difference in preschool curriculum knowledge based on professional qualifications. Private kindergarten teachers with Diploma in ECCE/Preschool Education and above demonstrated better preschool curriculum knowledge than ECCE/Preschool Teaching Certificates and None. This finding coincided with the findings of Nair and Yassin [29] which revealed that the early childhood teachers across Peninsular Malaysia with higher professional ECCE exhibited better comprehension in the ECCE curriculum and T\&L process than teachers with lower ECCE professional qualifications. Distinctly, teachers with professional qualifications had a better grasp of the needs and implementation of teaching that fit the development of children.

The findings of two-way ANOVA analysis further illustrated that there was a sign of inverse interaction between professional qualifications with experience towards preschool curriculum knowledge. Private kindergarten teachers with Diploma in ECCE/Preschool Education with experience of fewer than three years displayed the highest preschool curriculum knowledge. Private kindergarten teachers with 
Diploma in ECCE/Preschool Education and above with experience of 3-6 years was the third-highest. As for private kindergarten teachers with Diploma in ECCE/Preschool Education and above with experience of more than six years, they were the fourth and least. As expected, the experience served as a support for professional qualifications, especially during the early service years. Therefore, this finding could verify the study by Abdul Halim and Aznanche [8] which stated that four novice preschool teachers with professional qualification of bachelor's degree in preschool education with two years of experience showed T\&L skills coinciding with NSPC.

Interestingly, the same analysis findings also indicated that non-professionally qualified private kindergarten teachers with more than six years of experience had the second-highest preschool curriculum knowledge. This finding explained that even though experience helped the kindergarten teachers to develop knowledge on preschool curriculum, the knowledge became stagnant as experience increased. This means that the kindergarten teachers' experience acts as a support, but is inadequate to construct, enrich or develop their preschool curriculum knowledge, especially when there is curriculum change. This statement is almost identical to that of [23]. On the other hand, there is a limit in the finding to validate that experience has impacts on the practices of kindergarten teachers in implementing the preschool curriculum. Hence, it is suggested that future studies only determine the direct impacts of experience on the preschool curriculum to support the study by Tee and Mariani [30] which found that the principles of private preschool teachers with Malaysian Education Certificate (SPM) were still academic regardless of their 6-year experience.

Finally, one-way ANOVA analysis indicated that there was a difference in preschool curriculum knowledge based on professional development. The private kindergarten teachers involved in Others professional development program such as Malaysian Association of Islamic Kindergartens (PERTIM), Malaysian Association of Kindergartens (PTM), Malaysian Association of Kindergarten Teachers (PGTM), Private Preschool Teachers Training Program 2011 under the Department of National Unity and Integration (JPNIN), Q-Dees Training, Secretarial and Smart Reader demonstrated the highest preschool curriculum knowledge and had significant differences with KAAK and None. Private kindergarten teachers involved in KAP were the second-highest while as for NSPC Courses, the third-highest. The second least would be the private kindergarten teachers with None involvement in professional development. This finding proved how kindergarten teachers' involvement in professional development gave commendable knowledge on preschool curriculum compared to those without professional development. While this finding supported a previous study by Sofiah and Kamarul [10], it was not able to validate the factors, influence or main impacts of either NSPC Course, SKM Courses, KAAK, KAP or Others towards preschool curriculum knowledge.

From the abovementioned discussion, the findings of this study had validated two professional identities such as professional qualifications and professional development respectively in helping kindergarten teachers to gain better preschool curriculum knowledge, while experience as a support for professional qualifications during early service years. The three professional identities have separate functions in developing knowledge and understanding of kindergarten teachers on preschool curriculum and further developing their professionalism in implementing it. Hence, these findings are able to describe the concept of professional identity for kindergarten teachers according to the local context more distinctly. For that reason, the findings validated that the concept of professional identity is the professional background obtained by the kindergarten teachers through professional qualifications, experience and professional development which could potentially develop their professionalism in either understanding the preschool curriculum, planning as well as conducting more vibrant, effective and suitable T\&L for the children's needs.

\subsection{Limitation and recommendation for further research}

As per the previous discussion, this research is a preliminary study regarding professional identity on the preschool curriculum. The findings of this study merely surveyed the preschool curriculum knowledge based on professional identity to clearly determine the concept of professional identity through comparison analysis and hypothesis testing. Hence, this study by the survey has limits to validate the factors, influence, control or main impacts of professional identity (professional qualifications, experience or professional development) towards knowledge, comprehension or practices of kindergarten teachers on the preschool curriculum. Further research should use a new analysis whether by regression or ANCOVA test to determine the factors, influence or control of one of the three professional identities or by using qualitative analysis to ascertain the main impacts of professional identity. With the aforementioned analysis, the research on the professionalism of kindergarten teachers towards preschool curriculum would be enhanced.

\section{CONCLUSION}

On the basis of the constructed hypothesis to verify the definition of professional identity, three professional identities defined through works of literature such as professional credentials, experience and 
professional growth were confirmed. This study included 269 samples of private preschool teachers selected through stratified random sampling in a district in Selangor. While this study has limitations in some aspects as discussed, it is capable of proving that the three professional identities such as professional qualifications, experience and professional development are the professionalism requirements for the new preschool curriculum in Malaysia. Kindergarten teachers with higher professional qualifications and involved with professional development are proved to have better preschool curriculum knowledge, while the experience is support for them, especially during the early years of service. By meeting the objectives of the study, this study has successfully conceptualized the professional identities for kindergarten teachers through the Malaysian context. Thus, the literature results and findings of study create rooms and opportunity for ECCE and preschool education scholars to further research on the professionalism of kindergarten teachers and preschool curriculum.

\section{ACKNOWLEDGEMENTS}

This long-term research grant scheme (LRGS) research is supported by the ministry of finance (MOF) through the ministry of education (MOE) Malaysia. We thank the National Child Development Research Centre (NCDRC), Universiti Pendidikan Sultan Idris (UPSI) as the leading university in this study in collaboration with SEGi University. The title of this study is "Development of a Comprehensive and Integrated Model of Quality Malaysian Early Childhood Care and Education (2015-0024-106-04) with the sub-project is Project 1/CUR: Evaluation of Existing ECCE Programs to Improve Quality that Inform Policy" (2015-0024-106-04-1). It is funded by the Ministry of Finance through the Ministry of Education Malaysia. We thank all members of the research team who have contributed to this research. The authors also thank the steering committee, critical informants, teachers, parents and other stakeholders who participated in the study.

\section{REFERENCES}

[1] A. R. Mohd Nazri and B. W. M. N. Wan Nurul, "Implementation of National Preschool Curriculum Standard Curriculum 2017: Teacher retention,” JuPiDi: Journal of Educational Leadership, vol. 5, no. 3, pp. 59-71, 2018.

[2] L. Heikonen, et al., "Early career teachers' sense of professional agency in the classroom: Associations with turnover intentions and perceived inadequacy in teacher-student interaction," Asia-Pacific Journal of Teacher Education, vol. 45, no. 3, pp. 250-266, 2017.

[3] A. Anis, et al., "Challenges faced by Malaysian private HLIs in providing quality education: a thematic analysis," Quality Assurance in Education, vol. 26, no. 3, pp. 349-373, 2018.

[4] N. Mamat, et al., "Reliability, Validity and Fairness of Interviews for Teaching and Learning Project in Quality Early Childhood Care and Education: Preliminary Study," International Journal of Academic Research in Business and Social Sciences, vol. 8, no. 6, pp. 1283-1292, 2018.

[5] S. Schuck, et al., "The experiences of early career teachers: new initiatives and old problems," Professional Development in Education, vol. 44, no. 2, pp. 209-221, 2018.

[6] A. Mardziah, et al., "Students' assessment administration among preschool teachers," International Journal of Academic Research in Business and Social Sciences, vol. 7, no. 10, pp. 411-418, 2017.

[7] N. Beaver, et al., Early education curriculum: A child's connection to the world. US, Boston: Cengage Learning, 2018.

[8] M. Abdul Halim and A. Aznanche, "New preschool teachers teaching skills," Research Journal of Social Sciences, vol. 8, no. 11, pp. 14-19, 2015.

[9] Z. M. J. Amirafiza, et al., "Effective teaching of kindergarten teachers: A preliminary study," Journal of Educational Leadership, vol. 3, no. 4, pp. 72-95, 2016.

[10] M. Sofiah and A. J. Kamarul, "Knowledge of Islamic education preschool teachers in the civilized society development framework," Humanika Science, vol. 8, no. 3-2, pp. 21-28, 2016.

[11] S. Simon, "A Study of Primary School Parents' Interaction with Teachers' in Malaysia," World Academy of Science, Engineering and Technology International Journal of Educational and Pedagogical Sciences, vol. 11, no. 2, pp. 359-366, 2017.

[12] C. P. Brown, et al., The Wiley Handbook of Early Childhood Care and Education. New Jersey, United States, John Wiley \& Sons, 2019.

[13] K. Cheong, et al., "Employment as a journey or a destination? Interpreting graduates' and employers' perceptions-a Malaysia case study," Studies in Higher Education, vol. 43, no. 4, pp. 702-718, 2018.

[14] N. Nordin and M. A. Samsudin, "Professional Identity Formation in Globalization Era: Case of Malaysian Novice Teachers," Global Business \& Management Research, vol. 9, pp. 193-205, 2017.

[15] C. M. Wotipka, et al., "The worldwide expansion of early childhood care and education, 1985-2010," American Journal of Education, vol. 123, no. 2, pp. 1-14, 2017.

[16] A. H. Masnan, et al., "New preschool teachers and implementation of inclusive classes issues in Malaysia," International Journal of Academic Research in Business and Social Sciences, vol. 7, no. 10, pp. 644-652, 2017. 
[17] L. Foong, et al., "Private sector early child care and education in Malaysia: Workforce readiness for further education," Kajian Malaysia, vol. 36, no. 1, pp. 127-154, 2018

[18] A. Abd Khalil, "Model design for Malaysian teachers' professional development program," Doctor of Philosophy Thesis, Faculty of Education, Universiti of Malaya, 2017.

[19] R. Naylor and Y. Sayed, "Teacher quality: Evidence review," Canberra, Australia: Department of Foreign Affairs and Trade, 2014.

[20] H. Löfgren, "Teachers' work with documentation in preschool: Shaping a profession in the performing of professional identities," Scandinavian Journal of Educational Research, vol. 59, no. 6, pp. 638-655, 2015.

[21] A. Androusou, and V. Tsafos, "Aspects of the professional identity of preschool teachers in Greece: Investigating the role of teacher education and professional experience," Teacher Development, vol. 22, no. 4, pp. 554-570, 2018.

[22] A. R. O'Keefe, et al., "Exploring early childhood educators' notions about professionalism in Prince Edward Island," Journal of Childhood Studies, vol. 44, no. 1, pp. 20-36, 2019.

[23] M. Lunenberg and F. Korthagen, "Experience, theory, and practical wisdom in teaching and teacher education," Teachers and Teaching, vol. 15, no. 2, pp. 225-240, 2009.

[24] J. K. Rice, "The impact of teacher experience examining the evidence and policy implications, Brief No. 11," National Center for Analysis of Longitudinal Data in Education Research, vol. 1, pp. 1-8, 2010.

[25] S. Ntumi, "Challenges pre-school teachers face in the implementation of the early childhood curriculum in the Cape Coast Metropolis," Journal of Education and Practice, vol. 7, no. 1, pp. 54-62, 2016.

[26] L. Shulman, "Knowledge and teaching: Foundations of the new reform," Harvard Educational Review, vol. 57, no. 1, pp. 1-23, 1987.

[27] R. V. Krejcie and D. W. Morgan, "Determining sample size for research education and psychological measurement," Education and Psychological Measurement, vol. 30, no. 3, pp. 607-610, 1970.

[28] C. N. C. Ahmad, et al., "Development and validation of teacher perception on Early Childhood Care and Education Curriculum Instrument (ECCECI)," International Journal of Academic Research in Business \& Social Sciences, vol. 8, no. 1, pp. 716-727, 2018.

[29] S. M. Nair and S. M. Yassin, "Do preschool teachers' professional qualifications play a role in enhancing their understanding of ECCE training?" International Journal of Asian Social Science, vol. 7, no. 9, pp. 754-763, 2017.

[30] Y. Q. Tee and M. N. Mariani, "Exploring issues on teaching and learning in Malaysian private preschools," Malaysian Online Journal of Educational Management (MOJEM), vol. 6, no. 2, pp. 67-82, 2018. 